\title{
Target-site Mutation and Fitness Cost of Acetolactate Synthase Inhibitor- resistant Annual Bluegrass
}

\author{
Te-Ming Tseng ${ }^{2,5}$, Swati Shrestha ${ }^{3}$, James D. McCurdy ${ }^{2}$, Erin Wilson ${ }^{4}$, \\ and Gourav Sharma ${ }^{1,3}$ \\ Plant and Soil Sciences Department, Mississippi State University, Mississippi \\ State, MS 39762
}

Additional index words. ALS inhibitor, DNA sequence mutation, fitness penalty, herbicide resistance, turfgrass

\begin{abstract}
Annual bluegrass (Poa annua L.) is an annual weed that is particularly troublesome in managed turfgrass. It has been controlled conventionally with herbicides, including acetolactate synthase (ALS) inhibitors. However, resistance to ALS inhibitors has been documented throughout the southeastern United States since 2012. A rateresponse trial was conducted to confirm and determine the resistance level of suspected resistant $P$. annua biotypes from Mississippi (Reunion), followed by DNA sequencing to determine whether the mechanism of resistance is a target-site mutatio $\mathrm{n}$. In addition, a fitness assay was conducted together with a susceptible biotype to determine whether resistance to ALS inhibitors is associated with decreased fitness. Reunion was at least 45 times more resistant to foramsulfuron than the standard susceptible biotype based on $I_{50}$ estimates $\left[I_{50}\right.$ is the rate of herbicide giving a $50 \%$ response $(50 \%$ visual necrosis)], requiring a predicted $331 \mathrm{~g}$ a.i./ha foramsulfuron for $50 \%$ control. DNA sequencing results identified a Trp574-to-Leu mutation in the ALS gene of the Reunion biotype, which has been shown by other studies to confer resistance to ALS inhibitors. Measurement of fitness parameters among the Reunion and susceptible biotypes demonstrated reduced seed yield, tillering, and flowering time in the resistant Reunion biotype, suggesting that ALS inhibitor resistance is possibly correlated to decreased fitness in $P$. annua. Alternative methods to control $P$. annua need to be considered as a result of the evolution of herbicide-resistant biotypes. An integrated management strategy to control $P$. annua weeds will help prevent further evolution of resistance. Because this study evaluated only the target-site mechanism of resistance, it is also necessary to determine whether the resistant biotype has reduced uptake, translocation, or enhanced metabolism as additional mechanisms of resistance. Consequently, a fitness study encompassing a more comprehensive list of plant parameters will provide conclusions of the fitness costs associated with ALS

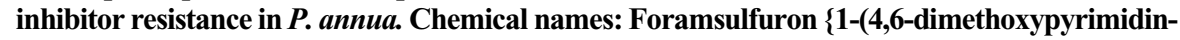
2-yl)-3-[2-(dimethylcarbamoyl)-5-formamidophenylsulfonyl] urea\}.
\end{abstract}

Annual bluegrass (Poa annua) is considered a most problematic annual winter weed in managed turfgrass, such as golf courses (Cross et al., 2013). This weed has traditionally been controlled by herbicides; however, populations that are resistant to various herbicides have been identified and studied (Brosnan et al., 2015; Heap, 2017; Kelly et al., 1999; McElroy

Received for publication 21 Aug. 2018. Accepted for publication 13 Dec. 2018.

We thank Brittany Jones for assisting with the DNA sequencing procedures. This material is based on work that is supported by the National Institute of Food and Agriculture, U.S. Department of Agriculture, Hatch project under accession number 230060, and is a contribution of the Mississippi Agricultural and Forestry Experiment Station.

${ }^{1}$ Current address: Department of Plant Pathology, Physiology, and Weed Science, Virginia Tech, Blacksburg, VA, 24061.

${ }^{2}$ Assistant professor.

${ }^{3}$ Graduate student.

${ }^{4}$ Undergraduate student.

${ }^{5}$ Corresponding author. E-mail: t.tseng@msstate. edu. et al., 2013). In the United States, $P$. апnua accounts for more than half of reported herbicide resistance in managed turfgrass system since the 1980 s, including populations resistant to photosystem II inhibitors, microtubule inhibitors, 5-enolpyruvylshikimate-3-phosphate synthase inhibitors, and, most recently, ALS inhibitors (Heap, 2012). Since 2012, the number of biotypes of $P$. annua resistant to ALS inhibitors has been increasing faster than any other mechanisms of action, resulting in resistant populations in Tennessee, Alabama, South Carolina, and Georgia (Brosnan et al., 2015; Heap, 2012). Annual bluegrass biotypes resistant to ALS inhibitors have not been documented previously in Mississippi.

One Mississippi biotype, Reunion, collected on 14 Feb. 2014, from Reunion Golf and Country Club in Madison, MS, was reported initially to have a diminished response to ALS-inhibiting herbicides foramsulfuron, flazasulfuron, and trifloxysulfuron. ALS-inhibiting herbicides work by inhibiting ALS (EC 2.2.1.6), which is the first enzyme in the branched-chain amino acid synthesis pathway that produces leucine, isoleucine, and valine (Umbarger, 1978). Inhibiting this enzyme results in plant death resulting from a lack of these essential amino acids (Ray, 1984; Tranel and Wright, 2002). The most effective ALS-inhibiting herbicides for $P$. annua are in the sulfonylurea family, and they include herbicides such as foramsulfuron, trifloxysulfuron, and rimsulfuron (Toler et al., 2007). However, herbicides in the sulfonylurea family are also more susceptible to the development of herbicideresistant biotypes (Tranel and Wright, 2002). One reason for the rapid development of $P$. annua biotypes resistant to ALS inhibitors on managed turfgrass is repeated use of herbicide without alternating the modes of action (Cross et al., 2013; McElroy et al., 2013). The most common mechanism of resistance to ALS inhibitors in plants is through a mutation of the ALS gene, usually through a single nucleotide point mutation that changes the amino acid sequence of the ALS protein (Cross et al., 2013; Tranel and Wright, 2002). There are six target sites in the ALS gene that, when mutated, commonly confer resistance to ALS inhibitors: Ala ${ }_{122}$, Pro $_{197}, \mathrm{Ala}_{205}, \mathrm{Asp}_{376}, \mathrm{Trp}_{574}$, and $\mathrm{Ser}_{653}$ (Tranel and Wright, 2002). In 2011, the first $P$. annua biotype not controlled by ALS inhibitors was reported in Alabama. McElroy et al. (2013) reported that this biotype had an amino acid substitution of $\operatorname{Trp}_{574}$ to Leu in the ALS gene. This specific mutation has been correlated with the most resistant biotypes of $P$. annua (Cross et al., 2015).

Plant fitness can be defined as the capability of a phenotype to produce offspring successfully relative to another phenotype. The fitness cost associated with herbicide resistance is the reduction of plant fitness in a stress-free environment as a result of negative pleotropic effects of herbicide-resistant alleles (Powles and $\mathrm{Yu}, 2010$ ). Parameters used most often to assess plant fitness associated with herbicide-resistant phenotypes are seed germination, longevity, dormancy, growth rate (plant height), competitive ability, biomass, and seed yield (Holt and Thill, 1994). ALS inhibitor-resistant Lactuca serriola plants containing the $\mathrm{Pro}_{197} \mathrm{His}$ allele decreased in frequency by as much as $86 \%$ over a 3 -year period, primarily because of reduced shoot biomass compared with susceptible plants (Alcocer-Ruthling et al., 1992). Similarly, Amaranthus powellii, with the $\operatorname{Trp}_{574} \mathrm{Leu}$ allele, showed significantly smaller and distorted leaves compared with susceptible plants (Tardif et al., 2006). Roots and shoots of susceptible plants were more developed and had $34 \%$ greater biomass than resistant plants (Tardif et al., 2006). These studies indicate the adverse pleotropic effects of resistanceassociated mutations on the growth and development of plants, thus reducing overall fitness.

Because certain resistant biotypes are found to have a fitness cost associated with them, the objectives of this study were 1) to confirm and determine the resistance level of the Mississippi biotype, Reunion, compared with a susceptible $P$. annua biotype; 2 ) to determine whether resistance is the result of 
to a target-site mutation in the ALS gene; and 3 ) and to determine whether resistance to ALS inhibitors in the resistant Reunion biotype is associated with any fitness penalty.

\section{Materials and Methods}

Plant material. Research was conducted using the resistant $P$. annua biotype Reunion collected from the Reunion Golf and Country Club, Madison, MS. A susceptible biotype collected in Starkville, MS, was used as a standard comparison. Seeds of each biotype were sown in 15-cm-diameter polypropylene containers with a commercial potting mix (Sunshine Mix \#1; Sun-Gro Horticulture, Bellevue, WA), followed by incubation in a growth chamber with day and night temperatures of 24 and $19{ }^{\circ} \mathrm{C}$, respectively. Light intensity was $21 \mu \mathrm{mol} \cdot \mathrm{m}^{-2} \cdot \mathrm{s}^{-1}$ with a $16-\mathrm{h}$ photoperiod. Plants matured for $\approx 12$ weeks until they were screened for resistance using 29 and $58 \mathrm{~g}$ foramsulfuron/ha (Revolver Herbicide; Bayer Environmental Science, Research Triangle Park, NC), equivalent to one and two times the rates, respectively. Eight potted replicates of each biotype were randomly assigned a 29 or $58 \mathrm{~g}$ a.i./ha foramsulfuron herbicide treatment. Plants were allowed to flower and produce seed in preparation for the greenhouse rate-response trial. The seeds were cleaned, dried, and stored at $4{ }^{\circ} \mathrm{C}$ for future testing.

Rate-response trial. Two experiments were conducted during 2015. Seeds collected from a previous screening experiment were lightly scarified and planted in $10-\mathrm{cm}-$ diameter plastic pots containing a Marietta silt loam (fine-loamy, siliceous, active; Fluvaquentic Eutrudepts) with pH 6.2 (1:1 soil/ $\mathrm{H}_{2} \mathrm{O}$ ) amended with $10 \%$ sand and $10 \%$ Sunshine Mix \#1 potting mix (Sun-Gro Horticulture). Plants received natural daylight, and irrigation was applied daily or as needed to prevent drought stress. Pots were fertilized weekly with Miracle-Gro ${ }^{\circledR}$ Water Soluble All Purpose Plant Food (Scotts Miracle-Gro Products, Inc., Marysville, OH; 28-8-16; $5.8 \mathrm{~kg} \mathrm{~N} / \mathrm{ha}$ ). A standard herbicide rateresponse trial was conducted twice (commenced 27 Feb. and 13 Mar.) as a completely randomized design with four replicates and one plant per experimental unit. To facilitate sigmoidal response predictions, foramsulfuron was applied at 1/4, 1/2, 1, 2, 4, 8, 16, and 32 times rates to both biotypes (Table 1)

Table 1. Foramsulfuron rates applied to Poа аппиа during rate-response screenings.

\begin{tabular}{lc}
\hline Times rate $^{z}$ & g a.i./ha \\
\hline 0.25 & 7 \\
0.5 & 15 \\
1 & 29 \\
2 & 58 \\
4 & 116 \\
8 & 232 \\
16 & 464 \\
32 & 928 \\
\hline
\end{tabular}

${ }^{\mathrm{z}} \mathrm{A}$ one-time rate was based on label recommendations for a P. апnиа control in field conditions.
(Cross et al., 2013). Rates were based on label recommendations (one time) for $P$. annua control. Treatment was applied in an enclosed research spray cabinet through a single TeeJet TP8002EVS nozzle (TeeJet $^{\circledR}$ TP8002EVS; Spraying Systems Co., Wheaton, IL) in a water carrier volume of $280 \mathrm{~L} \cdot \mathrm{ha}^{-1}$. Plants were allowed to dry for $30 \mathrm{~min}$ before being returned to the greenhouse. Irrigation was withheld for $24 \mathrm{~h}$. Pots were rerandomized twice weekly to account for variations in greenhouse microclimate.

Percent visual necrosis (PVN) was recorded 4 weeks after treatment (WAT). PVN ratings were based on a 0 to $100 \%$ scale, with $0 \%$ corresponding to no visible necrosis and $100 \%$ corresponding to complete plant necrosis. Data were analyzed by rating date using a log-logistic regression technique described by Seefeldt et al. (1995), where the $0-\mathrm{kg} \cdot \mathrm{ha}^{-1}$ herbicide rate was assigned artificially at the $0.0001-\mathrm{kg} \cdot \mathrm{ha}^{-1}$ rate. The analysis was conducted with Prism ${ }^{\circledR}$ (GraphPad Software, La Jolla, CA) using the model:

$$
y=C+\left[\frac{D-C}{1+\left(\frac{x}{I_{50}}\right)^{b}}\right],
$$

where $y$ is the response (PVN) at herbicide dose $x, D$ is the upper limit for $y, C$ is the lower limit for $y, b$ is the slope of the line at $I_{50}$, and $I_{50}$ is the rate of herbicide giving a $50 \%$ response (50\% visual necrosis). Best-fit parameters were determined by allowing the four parameters $\left(D, C, b\right.$, and $\left.I_{50}\right)$ to differ for each biotype. The slope and $I_{50}$ best-fit parameter estimates were compared between cultivars using an F test analysis of variance with a significance level of 0.05 (Seefeldt et al., 1995). The tolerance level of biotypes was compared using $I_{50}$ values (Streibig, 1988).

Target-site gene sequencing. Leaf tissue from five plants of each of the Reunion and susceptible biotypes was harvested at the two- to three-tiller stage, frozen in liquid nitrogen, and stored at $-80{ }^{\circ} \mathrm{C}$ until DNA extraction was performed. Tissue was ground to a fine powder using a mortar and pestle containing liquid nitrogen, and DNA isolation was conducted using a modified hexadecyltrimethylammonium bromide protocol (Doyle and Doyle, 1990). The DNA pellet was dissolved in TE buffer (Trisethylenediaminetetraacetic acid buffer), and a NanoDrop 2000c spectrophotometer (NanoDrop Technologies, Wilmington, DE) was used for DNA quantification before polymer- ase chain reaction (PCR) amplification of the potential ALS mutation site. PCR was performed using a MyCycler thermal cycler (BioRad, Richmond, CA) in a $25 \mu \mathrm{L}$-volume containing LongAmp Taq $2 \times$ Master Mix (New England Biolabs Inc., Beverly, MA) (125 U/mL Taq DNA polymerase, $0.3 \mathrm{~mm}$ dNTPs), $0.1 \mu \mathrm{M}$ forward primer $\left(5^{\prime}-\mathrm{TGG}\right.$ GCG GCT CAG TAT TAC AC-3'), $0.1 \mu \mathrm{M}$ reverse primer $\left(5^{\prime}\right.$-ATA GGC AGC ACA TGC TCC TG-3') (Yu et al., 2008), 150 ng DNA, and nuclease-free water. The thermocycler protocol started with denaturation at $94{ }^{\circ} \mathrm{C}$ for $4 \mathrm{~min}$, followed by 37 cycles of $94^{\circ} \mathrm{C}$ for 1 $\min , 55^{\circ} \mathrm{C}$ for $1 \mathrm{~min}$, and $72{ }^{\circ} \mathrm{C}$ for $2 \mathrm{~min}$. The final extension step continued for $5 \mathrm{~min}$ at $72{ }^{\circ} \mathrm{C}$. After amplification, gel electrophoresis was used to confirm success of the PCR amplification and to verify the size of the product. The correct DNA band was then excised from the agarose gel and purified using Wizard SV Gel and the PCR Clean Up Kit (Promega, Madison, WI), and was sequenced (Eurofins MWG Operon, Huntsville, AL).

Investigation of plant fitness costs associated with ALS gene mutations. Five seeds each of the resistant biotype (Reunion) and susceptible biotype were placed on a $9 \times 9-\mathrm{cm}^{2}$ petri dish lined with filter paper, moistened with 5 $\mathrm{mL}$ distilled water, and placed in a growth chamber with a 16-h photoperiod, 21 $\mu \mathrm{mol} \cdot \mathrm{m}^{-2} \cdot \mathrm{s}^{-1}$ light intensity, and day/night temperatures of 24 and $20^{\circ} \mathrm{C}$, respectively. After 1 week of incubation, germinated seedlings from each biotype were transplanted to five 10-cm-diameter pots filled with Sunshine Mix \#1 potting soil (Sun Gro Horticulture Inc.), and Miracle-Gro ${ }^{\circledR}$ was supplied weekly. Shoot length and number of tillers were recorded every other day from $7 \mathrm{~d}$ after transplanting (DAT) until 25 DAT. Days to flowering were measured. Seed heads were harvested at maturity, and seeds were weighed to determine seed yield. The experiment was conducted in a completely randomized block design with two runs. Statistical analyses were performed using PROC GLM of SAS 9.4 (SAS Institute, Cary, NC) and means were separated by Fisher's protected least significant difference test at the $0.05 P$ level.

\section{Results}

Greenhouse rate-response trial. The rateresponse trials confirmed foramsulfuron resistance in the Reunion bio Data were similar across experimental timings; therefore, results were pooled for subsequent analysis. A significant biotype-by-herbicide

Table 2. Best-fit regression parameters $\pm 95 \%$ confidence intervals of Poa annua biotypes describing percent visual necrosis response to foramsulfuron.

\begin{tabular}{|c|c|c|c|c|c|}
\hline \multirow[b]{3}{*}{ Biotype } & \multirow[b]{2}{*}{$I_{50}$} & \multicolumn{2}{|c|}{$I_{50} 95 \%$ confidence limits } & \multirow{3}{*}{$\begin{array}{c}\text { Resistance } \\
\text { factor }\end{array}$} & \multirow[b]{3}{*}{$R^{2}$} \\
\hline & & Lower & Upper & & \\
\hline & - - & amsulfur & - & & \\
\hline Susceptible & 7.2 & 5.9 & 8.8 & - & 0.726 \\
\hline Reunion & 335.1 & 159.1 & 705.9 & 46.0 & 0.815 \\
\hline
\end{tabular}

$I_{50}=$ the rate of herbicide giving a $50 \%$ response ( $50 \%$ visual necrosis). 
rate interaction $(P<0.001)$ was detected, indicating biotypes responded differently to foramsulfuron rates. Both biotypes showed increased injury with increasing herbicide rate. The greatest PVN was observed $4 \mathrm{WAT}$, and no recovery occurred before 4 WAT. However, no rate of foramsulfuron completely controlled all experimental units of the Reunion biotype (Table 2). $I_{50}$ estimates from PVN (Fig. 1) indicate the Reunion biotype to be at least 45 times more resistant to foramsulfuron than the standard susceptible biotype, requiring a predicted $331 \mathrm{~g}$ foramsulfuron/ha for $50 \%$ control. The labeled rate of foramsulfuron is $29 \mathrm{~g}$ a.i./ha. The susceptible biotype required a predicted $7.2 \mathrm{~g}$ foramsulfuron/ha to achieve $50 \%$ control.

Target-site gene sequencing. The region around amino acid position 574 on the ALS gene was amplified to determine whether there was target-site mutation. The nucleotide sequence for the wild-type susceptible biotype was TGG, which encodes tryptophan (Fig. 2). The Reunion biotype, however, contained the sequence TTG, a missense mutation that causes a tryptophan-to-leucine mutation in the biotype. This mutation might

\section{Herbicide rate resulting in $\mathbf{5 0 \%}$ visual injury of Poa annua 4 WAT}

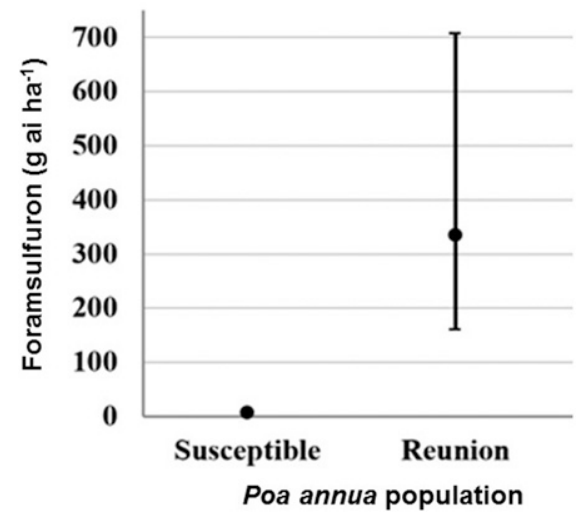

Fig. 1. Herbicide rate resulting in $50 \%$ visual necrosis of Poa annua 4 weeks after treatment (WAT). Based on $95 \%$ confidence intervals predicted by log-logistic regression. be responsible for annual bluegrass resistance to ALS-inhibiting herbicides.

Investigation of plant fitness costs associated with ALS gene mutations. There was no interaction between two runs, thus data from both the runs were pooled for analysis. In some cases, shoot growth of the Reunion biotype was slower than the susceptible biotype, and plant height of the Reunion and susceptible biotypes differed up to 19 DAT. Nevertheless, no difference in plant height was observed at 21 and 23 DAT (Fig. 3). The shoot length of the Reunion and susceptible biotypes 23 DAT was 9.6 and $9.2 \mathrm{~cm}$, respectively. On average, the Reunion biotype produced two to three tillers whereas the susceptible biotype produced five tillers. Flowering started 24 DAT in Reunion and 14 DAT in the susceptible biotype (Fig. 4). Average seed yield of the Reunion biotype was $47.5 \mathrm{mg}$; that of the susceptible biotype was $77.2 \mathrm{mg}$. Although Reunion had similar shoot length as the susceptible biotype, stems of Reunion were considerably thinner (data not shown), which may have resulted in their lower yield (Fig. 4).

\section{Discussion}

Herbicide resistance is a global problem and annual bluegrass is reported to have the greatest resistance issues of weeds in turfgrass systems. The Reunion biotype collected from the Reunion Golf and Country Club in Madison, MS, in 2014 was suspected of being resistant to ALS herbicides, and rateresponse trails confirmed this hypothesis. Target-site gene sequencing revealed a TGG-to-TTG mutation in Reunion, and this specific mutation has been identified as a mutation conferring resistance to ALS inhibitors not only in $P$. annua, but in other species as well (McElroy et al., 2013; Tranel and Wright, 2002). Patzoldt et al. (2001) observed the $\operatorname{Trp}_{574}$-to-Leu mutation in the ALS enzyme gene of Ambrosia artemisiifolia L., which is resistant to ALS inhibitors. Therefore, it appears that the Reunion biotype is resistant to ALS inhibitors through a Trp $_{574}$-to-Leu target-site mutation that alters the ALS enzyme. Although this result confirms the presence of target-site mutation in the Reunion biotype at position 574, it does not rule out the possibility of nontarget-site resistance completely. Nontarget-site resistance involves different mechanisms that are driven by differential gene expression (Duhoux et al., 2015). For example, Yu et al. (2009) studied nontarget-site mechanisms in annual ryegrass (Lolium rigidum) that conferred resistance to glyphosate-, ACCase-, and ALS-inhibiting herbicides. They discovered that a reduced translocation of glyphosate led to glyphosate resistance. Gardin et al. (2015) identified five P450 cytochromes that could possibly confer resistance to ALS inhibitors in black-grass (Alopercurus myosuroides), an annual weed. However, target-site mutations are the most common cause of ALS inhibitor herbicide resistance and, according to Tranel and Wright (2002), five amino acid mutations could confer resistance to ALS-inhibiting herbicides in numerous species. Point mutations at $\mathrm{Ala}_{122}, \mathrm{Pro}_{197}, \mathrm{Ala}_{205}, \mathrm{Trp}_{574}$, and $\mathrm{Ser}_{653}$ are found in weeds of many resistant biotypes (Corbett, 2004; Saari et al., 1994).

These mutations associated with resistance generally have minor effects on growth and development of resistant plants (Holt and Thill, 1994; Thompson et al., 1994). In our study, there was no difference in plant height between the resistant Reunion and the susceptible biotypes at 23 DAT. This is in contrast to studies that generally relate resistant alleles to adverse effects on hypocotyl length and plant height (Timpte et al., 1994, 1995). In Amaranthus powellii, roots and shoots of susceptible biotypes were four times thicker than the resistant biotype (Tardif et al., 2006). This difference in height and thickness between resistant and susceptible plants is attributed to the slower and reduced differentiation of primary and secondary tissues in resistant plants. In our study, susceptible plants produced five tillers whereas Reunion produced two to three tillers at 23 DAT. Herbicide resistance has an effect on tiller formation in certain weed species. Dinitroaniline and ACCase inhibitor-resistant Setaria viridis plants showed a greater number of tillers than susceptible plants (Darmency et al., 2011). However, a competitive study between susceptible and resistant Brachypodium hybridum to photosystem II inhibitors

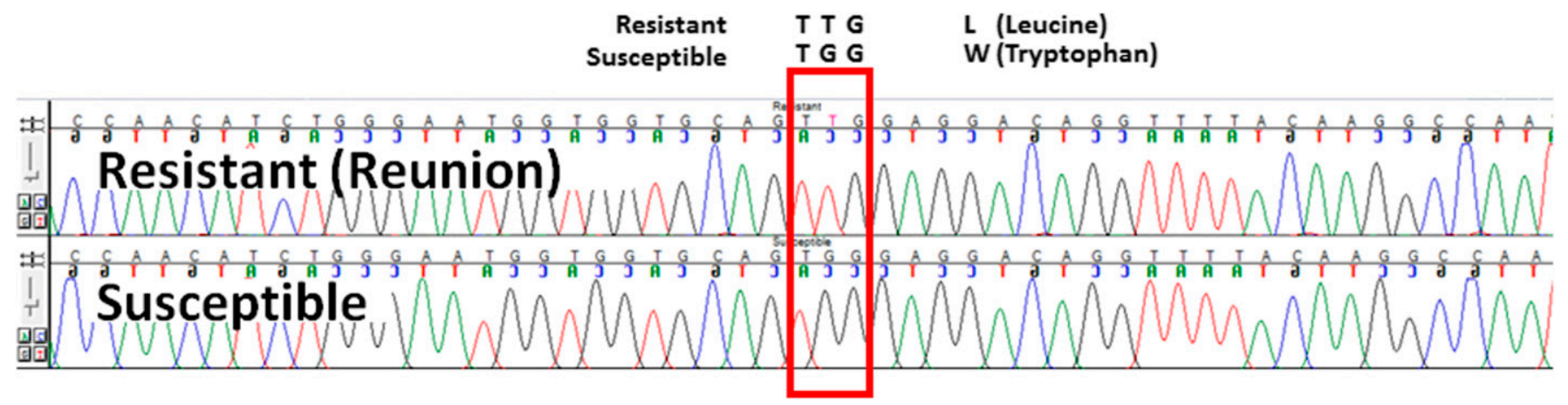

Fig. 2. Chromatogram of DNA sequencing results from each of the Poa annua biotypes tested. The nucleotides coding the position of interest (position 574) on the acetolactate synthase enzyme are boxed in the figure. The respective sequences and accompanying amino acids are enlarged at the top of the figure. 


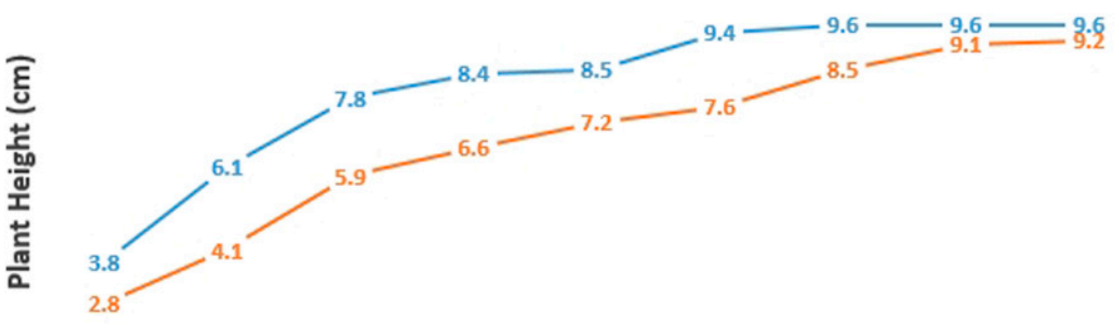

7

9

11

15

17

19

21

23

Days after transplanting (DAT)

- - S - - R

Fig. 3. Plant growth pattern in resistant biotype (Reunion) and susceptible biotype of Poa annua. The difference in plant height was statistically significant until $19 \mathrm{~d}$ after transplanting (DAT), and no difference in plant height was observed at 21 and 23 DAT.

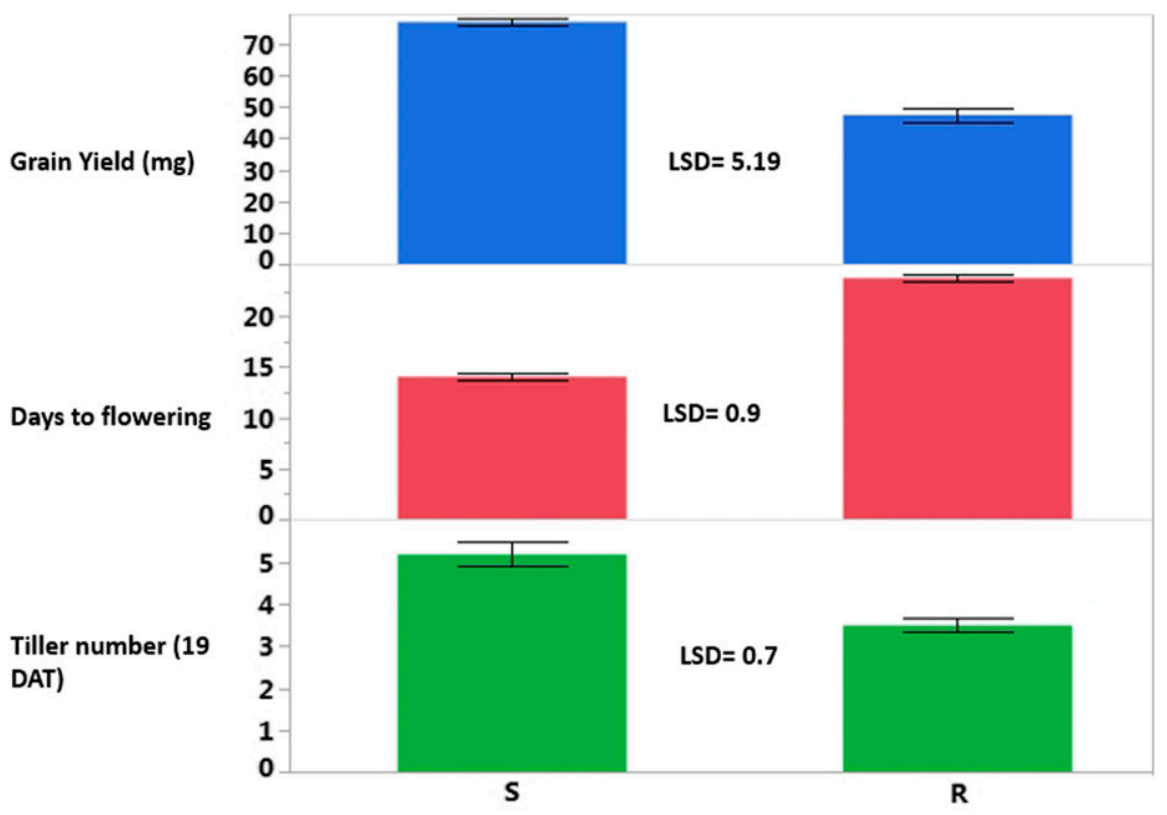

Biotype

Fig. 4. Difference in fitness traits between acetolactate synthase-resistant (Reunion, R) and acetolactate synthase-susceptible (S) biotype. Tiller number and seed yield (measured in milligrams) were recorded $25 \mathrm{~d}$ after transplanting (DAT). LSD = least significant difference. identified a significantly reduced number of tillers produced by a resistant compared with a susceptible biotype (Frenkel et al., 2017). This suggests different species might have variable fitness costs associated with herbicide resistance. A lesser number of tillers with ALS herbicide resistance in Reunion will ultimately lead to the production of fewer reproductive structures, eventually affecting seed yield negatively.

Flowering in Reunion occurred later (23 DAT) than the susceptible biotype (14 DAT) and produced a lower yield (47.5 $\mathrm{mg}$ ) than the susceptible biotype $(77.2 \mathrm{mg})$. Late flowering has a disadvantage because plants have greater chances of getting exposed to management strategies before

height, and flowering time-were inferior compared with the susceptible biotype in this study. Future research into $P$. annua control should include determination of a nonherbicidal means of control, because this weed develops resistance rapidly to multiple herbicide modes of action compared with other species. Although the Reunion biotype was shown to have a target-site mutation, additional testing is required to determine whether additional target-site mutations or nontargetsite mechanisms of resistance occurs.

Further research on the mechanism of herbicide resistance in resistant biotypes could include determining uptake, translocation, and metabolism of herbicide with ${ }^{14} \mathrm{C}$-labeled experiments using a liquid scintillation counter. A whole-plant assay to assess the fitness penalty in ALS inhibitorresistant plants using parameters such as seed yield, photosynthetic efficiency, and root characterization will provide a comprehensive picture of the reduced efficiency in the resistant $P$. annua biotype.

\section{Literature Cited}

Alcocer-Ruthling, M., D.C. Thill, and B. Shafii. 1992. Differential competitiveness of sulfonylurea resistant and susceptible prickly lettuce (Lactuca serriola). Weed Technol. 6:303-309.

Brosnan, J., T. Breeden, G.K. Vargas, and L. Grier. 2015. A biotype of annual bluegrass (Poa annиa) in Tennessee is resistant to inhibitors of ALS and photosystem II. Weed Sci. 63:321-328.

Corbett, C.L. 2004. DNA-based diagnostic tests for the detection of acetolactate synthaseinhibiting herbicide resistance in Amaranthus sp. Univ. of Guelph, ON, Canada, MS Thesis.

Cross, R.B., L. McCarty, J. McElroy, N. Tharayil, and W.C. Bridges. 2015. Comparison of enzyme and growth characteristics in ALS-inhibitor susceptible and resistant annual bluegrass (Poa аппиа) biotypes. Weed Sci. 63:220-228.

Cross, R.B., L. McCarty, N. Tharayil, T. Whitwell, and W.C. Bridges. 2013. Detecting annual bluegrass (Роа аппиа) resistance to ALSinhibiting herbicides using a rapid diagnostic assay. Weed Sci. 61:384-389.

Darmency, H., J.C. Picard, and T. Wang. 2011. Fitness costs linked to dinitroaniline resistance mutation in Setaria. Heredity 107:80-86.

Doyle, J.J. and J.L. Doyle. 1990. Isolation of plant DNA from fresh tissue. Focus 12:13-15.

Duhoux, A., C. Délye, S. Carrère, J. Gouzy, and L. Bonin. 2015. RNA-Seq analysis of ryegrass transcriptomic response to an herbicide inhibiting acetolactate-synthase identifies transcripts linked to non-target-site-based resistance. Plant Mol. Biol. 87:473-487.

seedbank in each generation. Late flowering also increases the life cycle of the weed decreasing their competitiveness. The Reunion biotype will thus have higher lower competitiveness than the susceptible bluegrass biotypes.

This study identified a fitness cost to herbicide resistance, as often hypothesized and reported (Frenkel et al., 2017; Panozzo et al., 2017; Yanniccari et al., 2016). Some species might have no fitness cost associated with herbicide resistance; other species have decreased competitiveness compared with their susceptible biotypes (Frenkel et al., 2017). All fitness parameters of the resistant biotype - seed yield, number of tillers, plant

Frenkel, E., M. Matzrafi, B. Rubin, and Z. Peleg. 2017. Effects of environmental conditions on the fitness penalty in herbicide resistant $\mathrm{Bra}$ chypodium hybridum. Front. Plant Sci. 8:94.

Gardin, J., J. Gouzy, S. Carrère, and C. Délye. 2015. ALOMYbase, a resource to investigate non-target-site-based resistance to herbicides inhibiting acetolactate-synthase (ALS) in the major grass weed Alopercurus myosuroides (black-grass). BMC Genomics 16:590.

Heap, I. 2012. The international survey of herbicide resistant weeds. 18 May 2017. <http://www. weedscience.org/Details/Case.aspx?ResistID= $5644>$.

Holt, J.S. and D.C. Thill. 1994. Growth and productivity of resistant plants, p. 299-316. In: 
S.B. Powles (eds.). Lewis Publishers, Boca Raton, FL.

Kelly, S.T., G.E. Coats, and D.S. Luthe. 1999 Mode of resistance of triazine-resistant annual bluegrass (Роа апnиа). Weed Technol. 13:747-752.

McElroy, J., M. Flessner, Z. Wang, F. Dane, R. Walker, and G.R. Wehtje. 2013. A Trp 574 to Leu amino acid substitution in the ALS gene of annual bluegrass (Poa апnиa) is associated with resistance to ALS-inhibiting herbicides. Weed Sci. 61:21-25.

Panozzo, S., L. Scarabel, M. Sattin, and V. Rosan. 2017. A new Ala-122-Asn amino acid change confers decreased fitness to ALS-resistant Echinochloa crus-galli. Front. Plant Sci. 8: 2042.

Patzoldt, W., P. Tranel, A. Alexander, and P. Schmitzer. 2001. A common ragweed population resistant to chloransulam-methyl. Weed Sci. 49:485-490.

Powles, S.B. and Q. Yu. 2010. Evolution in action: Plants resistant to herbicides. Annu. Rev. Plant Biol. 61:317-347.

Ray, T. 1984. Site of action of chlorsulfuron inhibition of valine and isoleucine biosynthesis in plants. Plant Physiol. 75(3):827-831.
Saari, L.L., J.C. Cotterman, and D.C. Thill. 1994. Resistance to acetolactate synthase inhibiting herbicides, p. 141-170. In: S.B. Powles and J.A.M. Holtum (eds.). Herbicide resistance in plants: Biology and biochemistry. CRC press, Boca Raton, FL.

Seefeldt, S.S., J.E. Jensen, and E.P. Fuerst. 1995. Log-logistic analysis of herbicide dose-response relationships. Weed Technol. 9:218-227.

Streibig, J.C. 1988. Herbicide bioassay. Weed Res. $28: 479-484$

Tardif, F.J., I. Rajcan, and M. Costea. 2006. A mutation in the herbicide target site acetohydroxyacid synthase produces morphological and structural alterations and reduces fitness in Amaranthus powellii. New Phytol. 169:251-264.

Thompson, C.R., D.C. Thill, and B. Shafii. 1994. Germination characteristics of sulfonylurearesistant and sulfonylurea-susceptible kochia (Kochia scopa-ria). Weed Sci. 42:50-56.

Timpte, C., C. Lincoln, and F.B. Pickett. 1995. The axrl and auxl genes of Arabidopsis function in separate auxin-response pathways. Plant J. 8:561-569.

Timpte, C., A.K. Wilson, and M. Estelle. 1994. The axr2-1 mutation of Arabidopsis thaliana is a gain-of-function mutation that disrupts an early step in auxin response. Genetics 138:12391249.

Toler, J.E., T.G. Willis, A.G. Estes, and L.B. McCarty. 2007. Postemergent annual bluegrass control in dormant nonoverseeded bermudagrass turf. HortScience 42:670-672.

Tranel, P. and T. Wright. 2002. Resistance of weeds to ALS-inhibiting herbicides: What have we learned? Weed Sci. 50:700-712.

Umbarger, H. 1978. Amino acid biosynthesis and its regulation. Annu. Rev. Biochem. 47(1): 533-606.

Yanniccari, M., M. Vila-Aiub, C. Istilart, H. Acciaresi, and A.M. Castro. 2016. Glyphosate resistance in perennial ryegrass (Lolium perenne L.) is associated with a fitness penalty Weed Sci. 64:71-79.

Yu, Q., I. Abdallah, H. Han, M. Owen, and S.B. Powles. 2009. Distinct non-target site mechanisms endow resistance to glyphosate, ACCase and ALS-inhibiting herbicides in multiple herbicide-resistant Lolium rigidum. Planta 230:713-723.

Yu, Q., H. Han, and S.B. Powles. 2008. Mutations of the ALS gene endowing resistance to ALSinhibiting herbicides in Lolium rigidum populations. Pest Mgt. Sci. 64:1229-1236. 